\title{
Sensory Preference and Mineral Contents of Cereal Bars Made From Glutinous Rice Flakes and Sunnah Foods
}

\author{
Rafiu Agbaje ${ }^{1}$, Chek Zaini Hassan ${ }^{1 *}$, Norlelawati Arifin ${ }^{1}$, \\ Asma Abdul Rahman ${ }^{2}$.

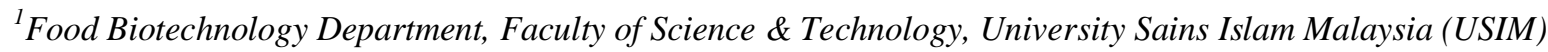 \\ Bandar Baru Nilai, 71800 Nilai,Negeri Sembilan,Malaysia. \\ ${ }^{2}$ Department of Arabic Communication, Faculty of Major Language Studies/University Sains Islam \\ Malaysia (USIM) Bandar Baru Nilai, 71800 NilaiNegeri Sembilan, Malaysia.
}

\begin{abstract}
Cereal bars were formulated using dry raw materials (glutinous rice, black Cummins, etc.) and binding agents (honey and glucose syrup). The dried fruits were mixed with the dry ingredients and binding ingredients at different percentages. The cereal bars were assessed for mineral element contents using microwave - assisted digestion method. The consumer acceptability of the cereal bars were carried out using 9hedonic scale. The cereal bar samples had sodium, 70.54-235.86mg/kg; calcium, 186.54-482.89mg/kg; iron, $33.64-41.52 \mathrm{mg} / \mathrm{kg} ;$ zinc, $29.76-50.95 \mathrm{mg} / \mathrm{kg} ;$ manganese, $12.52-17.05 \mathrm{mg} / \mathrm{kg} ;$ copper, $11.86-13.73 \mathrm{mg} / \mathrm{kg}$; magnesium, $88.00-160.14 \mathrm{mg} / \mathrm{kg}$. In the sensory analysis, it was found that the sample CB-C (honey-19.76\%, glucose syrup-13.18\% and $9.50 \%$ fruits) had the highest acceptability. All the qualities evaluated did not significantly $(p \leq 0.05)$ affect the acceptability and preference of the samples, except texture which shows a significant difference $(p \leq 0.05)$ among the samples. Hence, it was concluded that incorporation of halal/sunnah fruits into the production of cereal bars will still make it to retain much of the nutritional and sensory properties.
\end{abstract}

Keywords: cereal bar; Halal/Sunnah foods; mineral elements; sensory evaluation; snack food.

\section{INTRODUCTION}

There have been growing interests recently on the part of consumers, the food industry, and researchers into food and the ways in which it may help maintain human health. The major function played by diet in hindering and treating illnesses is extensively accepted [1]. At the same time there has been increase in the consumption of fast-foods and snacks which has made the market of cereal bar to increase [2]. The desire for nutritional and functional foods likewise increased at the same pace. Consumers do not eat these snacks only to provide satisfaction for their hunger, but also to supply necessary nutrients and prevent nutrition-related illnesses. As a result of rising consumer demand for wholesome, natural and convenient foods, efforts are being made to improve snack foods nutritional values by modifying their nutritive constituents. Cereal bars are a standard, well-accepted and convenient food which would be an ideal food format to deliver fruit-derived phenolic antioxidants and fibre [3].

Dietary fibre possesses many physicochemical functions which contribute to the physiological attenuation such as cholesterol and fat binding, decrease in blood glucose levels, prevention of constipation and facilitation of good colonic health. The most widely used cereals as dietary fibre source for products containing cereals are: wheat, oat, barley, rice, rye [4]. For this reason, the main cereal used in this study is glutinous rice. Glutinous rice is converted to flake which is used in the production of cereal bars. Selected Sunnah fruits like raisins, dates and figs are combined with these cereals and agglutination syrups (glucose syrup and honey) in different combinations to give desired DF content that will prevent nutrition-related diseases, asides the satisfaction of hunger and provision of necessary nutrients.

Cereal bars stand out among fast foods due to their balanced nutritional content and convenience [5]. Cereal bar, "granola" is a dry granulated cereal product which has a lower water activity [6]. Cereal bars are made from a compressed mixture of cereals and dried fruit. Generally, the glucose syrup is the aggregator element of the bar ingredients providing quick energy absorption [5]. Dutcosky et al. [7] opined that increased consumption of cereal bars is associated with the change of lifestyles and the need of fast meals and snacks. Consumers have easily accepted cereal bars because they are believed to be a nutritionally balanced high-fibre snacks. Also, because they have an adequate balance between energy, fat, protein, vitamins, minerals, fibre and whole grains are beneficial to consumer health [8]. Lima [9] reported that the greatest challenge in obtaining a good cereal bar is a combination of many ingredients with main functionality like minerals, vitamins, proteins, fibres, binding agents and turns them into a product with flavor, aroma, texture and decent appearance, while trying to achieve specific goals nutrients. 
It has been observed that processing of Sunnah foods has not received much attention. In the Holy Qur'an, Muslims are enjoined to consume Sunnah foods. Eating is regarded as a way of worshipping God (Allah) for Muslims [10]. A set of dietary rule called "Halal" (legal, permitted by Allah) is prescribed by Islamic law. This dietary rule lists the permitted food and prohibits the consumption of foods not obtained or prepared according to Islamic rules [11, 12]. "Halal" also means the aspects of reliable, food quality, wholesome, hygiene and safety. Muslims must strive to obtain halal food of good quality [13]. In the Holy Qur'an, Muslims are enjoined to consume Sunnah foods. Eating healthy foods and not excessively are encouraged in the Halal diet. As a result, Muslims who keep Halal diet will never overeat and become obese. Allah has repeatedly emphasised the consumption of Halal food in the Qur'an: "O mankind! Eat of that which is lawful and wholesome in the earth, and follow not the footsteps of the Devils. He is an open enemy for you". (Al- Quran. Al-Baqarah 2:168).

The Sunnah fruits used in this study are figs (Ficus carica), raisins (Vitis vinifera L.) and dates (Phoenix Dactylifera). The fruits are mentioned in the Holy Quran and Hadith as beneficial fruits. Prophet Muhammad (PBUH) also said "If I had to mention a fruit that descended from Paradise I would say it is the fig, because the fruits of Paradise do not have pits... eat from these fruits for they prevent hemorrhoids \& piles and help gout"(Tib Nab Awi, Hadith 467,page 486). Imam Ali (PBUH) refers to the grape and says: The grape is both a fruit and a food; it is sweet and delicious. Imam Ali (PBUH) not only refers to grape as a useful fruit, he also introduces it as a wholesome food. Grape is effective in removing sorrow, stress and depression. Prophet Muhammad (SAW) said "Dates are able to strengthen stomach, liver, memory, to grow body development, cure illness and as food and drink that sated." (Ibnu Qayyim in Tib An Nabawi).

The main aim of this study was to formulate cereal bar from selected Sunnah foods using glutinous rice flakes and honey and glucose syrup as a binding agent. The mineral contents of the cereal bar samples were evaluated. The objective of this research was to determine acceptability and preference of the samples (sensory evaluation) and mineral contents of cereal bars made from Sunnah foods.

\section{Materials and Method}

The glutinous rice and other ingredients: glucose syrup, apple sauce, brown sugar, honey, the dried fruits (dates, figs and raisins), black cumin and saffron were purchased at TESCO, Nilai, Malaysia. All the chemicals used for the study were of analytical reagent grade.

\subsection{Preparation of glutinous rice flakes}

Glutinous rice was thoroughly cleaned and soaked in water for 24 hours, steamed and dried overnight at temperature $155^{\circ} \mathrm{C}$ using an Excalibur Food Dehydrator Parallex (USA) to a moisture content of $6.75 \%$.

\subsection{Preparation of glutinous rice flakes cereal bar}

The dried fruits (dates, figs and raisins) were diced. Black cumin and saffron were added to the dried fruits in a stainless steel bowl. The contents were heated in an oven at $100^{\circ} \mathrm{C}$ for 15 minutes. The heating was done after all the ingredients were thoroughly homogenized with the binding agents. After heating in the oven, the mixture (cereal bar) was removed from the oven and allowed to cool before cutting into rectangular shapes; $11 \mathrm{~cm}$ long, $3 \mathrm{~cm}$ wide and $1.5 \mathrm{~cm}$ thick.

\subsection{Mineral Composition Determination}

Mineral elements, namely: $\mathrm{Na}, \mathrm{Ca}, \mathrm{Mg}, \mathrm{Fe}, \mathrm{Cu}, \mathrm{Zn}$, and $\mathrm{Mn}$ were determined by the microwave assisted digestion. The atomic absorption Spectrometer (Perkin-Elmer Analyst 800 AAS, USA) equipped with graphite furnace (GFAAS) and AS 800 auto sampler was used to determine the concentrations of the metals in the samples by flame atomization, using air acetylene flame and single element hollow cathode lamp.

\subsection{Sensory Evaluation}

Cereal bar samples were subjected to sensory evaluation. A panel of 60 consumers recruited from the faculty, students and staff at USIM. The following sensory attributes, namely taste, colour, texture, appearance and overall acceptability were assessed on the cereal bar samples. A 9-point hedonic scale with $1=$ extremely dislike, $5=$ moderately liked and $9=$ like extremely was used [14]. 


\subsection{Statistical Analysis}

All determinations were performed in triplicate. The statistical analyses were conducted using one-way ANOVA procedures. Statistical differences were tested for at $P \leq 0.05$. Tukey's test was used to differentiate between the mean values. All analyses were done with MINITAB (16.2.1 version software).

\section{Results And Discussion}

The sensory scores of appearance, colour, taste, texture and overall acceptability assigned by the panelists are presented in Table 3. The highest mean appearance score was recorded by CB-B, 6.40, though the scores were not significantly different $(\mathrm{p} \leq 0.05)$ from other formulations. CB-D had the highest mean score of 6.57 for colour which was not significantly different at $\mathrm{p} \leq 0.05$. Tastes mean score was higher for CB-E, 6.45 ; though not significantly different. It was observed that the texture scores were significantly different at $\mathrm{p} \leq$ 0.05.CB-C obtained highest texture score, 6.22. The highest mean for overall acceptance was obtained by sample CB-C, 6.58; but the scores were not significantly different $(\mathrm{p} \leq 0.05)$.

The cereal bars were similar in respect to sensory results of the appearance which were not significantly different for all the samples. Freitas and Moretti [15] produced cereal bars with banana flavor. The scores obtained in this study were higher than those obtained in their work (appearance -6.39 , taste -6.42 , texture -5.29 and overall liking -6.14 ). The sensory results obtained in this work were close to those obtained by de Carvaho et al. [16]. The results in their work were as follows: appearance (6.7-7.5), colour (6.8 - 7.6), flavor/taste (6.1- 6.9), texture (6.5 - 7.3) and overall acceptance (6.2 - 7.1). Santos et al. [17] obtained the following sensory results for their cereal bars made with jackfruit: $6.1-6.9$ (colour), 5.9- 7.1 (taste), 5.7-6.6 (texture) and 6.3 to 7.1 for global impression. Results obtained in this study were close to the results of Santos et al., [17]. According to results observed by Brito et al. [2], study of homemade cereal bars, the sensory scores were 4.2 -6.6 (appearance), and colour $(0.9-3.4)$ were below the scores obtained for cereal bars made with glutinous rice flakes and Sunnah fruits. With regards to the overall acceptance (6.1-6.9), the results were similar to those observed for bars in this work.

The results are not also far from what obtained in the studies about food bar made from whole flour from a new cultivar of Amaranth [18]. The scores for appearance ranged between 7.34-7.64, texture, 6.88-7.38, and overall acceptance, 6.91-7.38. The bars were regarded as well accepted once the acceptance rate was greater than $70 \%$ [19]. However, sample CB-C had the highest mean score for texture which might have contributed to its emergence as the sample with the highest acceptance [20].

Table 3 shows the mineral analysis results of the samples. Glutinous rice flakes cereal bars had 70.54$235.86 \mathrm{mg} / \mathrm{kg}$ for sodium; calcium, $186.54-482.89 \mathrm{mg} / \mathrm{kg}$ for calcium; $33.64-41.52 \mathrm{mg} / \mathrm{kg}$ for iron; $29.76-$ $50.95 \mathrm{mg} / \mathrm{kg}$ for zinc; $12.52-17.05 \mathrm{mg} / \mathrm{kg}$ for manganese; $11.86-13.73 \mathrm{mg} / \mathrm{kg}$ for copper; and $88.00-160.14 \mathrm{mg} / \mathrm{kg}$ for magnesium. Ananthan et al., [21] in their work obtained $68.34 \mathrm{mg} / \mathrm{kg}$ of calcium, $6.00 \mathrm{mg} / \mathrm{kg}$ of iron and $2.48 \mathrm{mg} / \mathrm{kg}$ of zinc. The minerals observed in this work were superior to those obtained by Ananthan and his coresearchers. Compared to Ananthan and others [22], protein rich composite cereal bar produced, had $8.9 \mathrm{mg} / \mathrm{kg}$ calcium, $8.2 \mathrm{mg} / \mathrm{kg}$ iron and $2.8 \mathrm{mg} / \mathrm{kg}$ zinc.

The results obtained in this work were higher which made this glutinous rice a better cereal for production of cereal bars. As it was displayed in table 1, the main mineral elements were magnesium and calcium for all the samples. These results are in line with the work Pagamunici et al. [18]. Magnesium play a crucial role in a wide range of biochemical and physiological actions and the incidence of calcium in the products enhance the increase in bioavailability and absorption of magnesium, manganese and zinc. The composition of the trace minerals; zinc and manganese were not significantly varied $(\mathrm{p} \leq 0.05)$. According to Hathcock [23], these trace minerals are vital for the repairs of biological systems because they contribute as cofactors in metabolic processes. Similar results were obtained by [18] and [24] who did study on cookies and granola respectively. Nonetheless, the results obtained in the formulations in this study are superior to findings obtained of Rehman et al. [25], studies of apricot-date bars. 
Sensory Preference and Mineral Contents of Cereal Bars Made From Glutinous Rice Flakes and

IV. FIGURES AND TABLES

Table 4.1. Final Formulation of Cereal Bars made from Selected Sunnah Fruits

\begin{tabular}{|c|c|c|c|c|c|c|c|}
\hline \multirow[b]{2}{*}{ Samples } & \multicolumn{7}{|c|}{ Percentage $(\%)$} \\
\hline & $\begin{array}{c}\text { Glutinous rice } \\
\text { flakes }\end{array}$ & Dates & Raisin & Figs & Black cumin & Honey & $\begin{array}{c}\text { Glucose } \\
\text { syrup }\end{array}$ \\
\hline CB-A & 49.21 & 2.46 & 2.46 & 2.46 & 0.74 & 25.59 & 17.08 \\
\hline CB-B & 47.19 & 2.36 & 2.36 & 2.36 & 0.71 & 12.27 & 37.52 \\
\hline $\mathrm{CB}-\mathrm{C}$ & 37.99 & 9.50 & 9.50 & 9.50 & 0.57 & 19.76 & 13.18 \\
\hline CB-D & 36.77 & 9.19 & 9.19 & 9.19 & 0.55 & 9.56 & 25.52 \\
\hline CB-E & 42.88 & 6.43 & 6.43 & 6.43 & 0.64 & 22.30 & 14.88 \\
\hline CB-F & 41.34 & 6.20 & 6.20 & 6.20 & 0.62 & 10.75 & 28.69 \\
\hline
\end{tabular}

Table 4.2. Mineral composition of the glutinous rice flakes cereal bars made from selected Sunnah fruits in

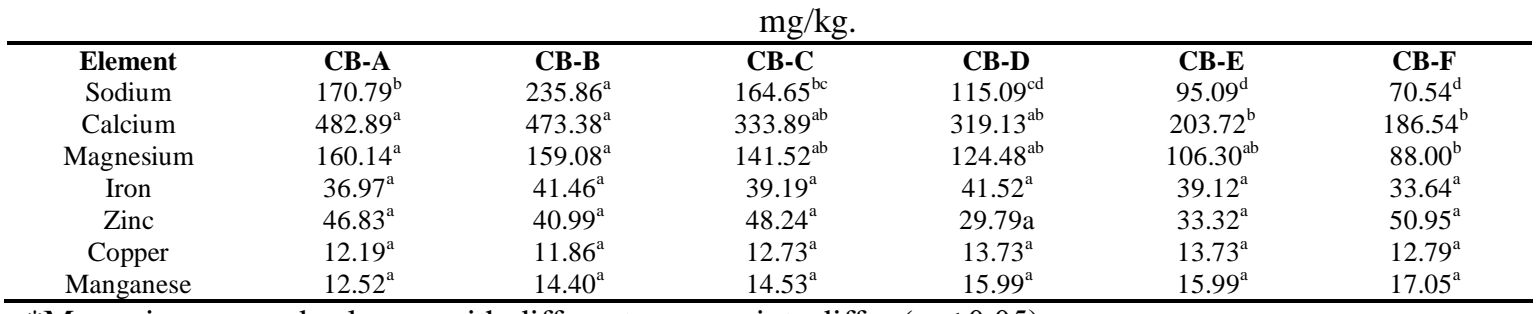

*Means in rows and columns with different superscripts differ $(\mathrm{p} \leq 0.05)$.

Table 4. 3. Sensory Analysis of the glutinous rice flakes cereal bars made from selected Sunnah fruits.

\begin{tabular}{cccccc}
\multicolumn{6}{c}{ Table } \\
\hline Samples & 3. Sensory Analysis of the glutinous rice flakes cereal bars made from selected Sunnah fruits. \\
CB-A & Appearance & Colour & Taste & Texture & Overall acceptance \\
CB-B & $6.22^{\mathrm{a}}$ & $6.20^{\mathrm{a}}$ & $6.00^{\mathrm{a}}$ & $5.33^{\mathrm{ab}}$ & $5.85^{\mathrm{a}}$ \\
CB-C & $6.40^{\mathrm{a}}$ & $6.53^{\mathrm{a}}$ & $6.28^{\mathrm{a}}$ & $5.83^{\mathrm{ab}}$ & $6.45^{\mathrm{a}}$ \\
CB-D & $6.35^{\mathrm{a}}$ & $6.37^{\mathrm{a}}$ & $6.43^{\mathrm{a}}$ & $6.22^{\mathrm{a}}$ & $6.58^{\mathrm{a}}$ \\
CB-E & $6.35^{\mathrm{a}}$ & $6.57^{\mathrm{a}}$ & $6.28^{\mathrm{a}}$ & $5.87^{\mathrm{ab}}$ & $6.42^{\mathrm{a}}$ \\
CB-F & $6.12^{\mathrm{a}}$ & $6.25^{\mathrm{a}}$ & $6.45^{\mathrm{a}}$ & $5.83^{\mathrm{ab}}$ & $6.40^{\mathrm{a}}$ \\
\hline
\end{tabular}

* Means in rows and columns with different superscripts differ $(\mathrm{p} \leq 0.05)$. 


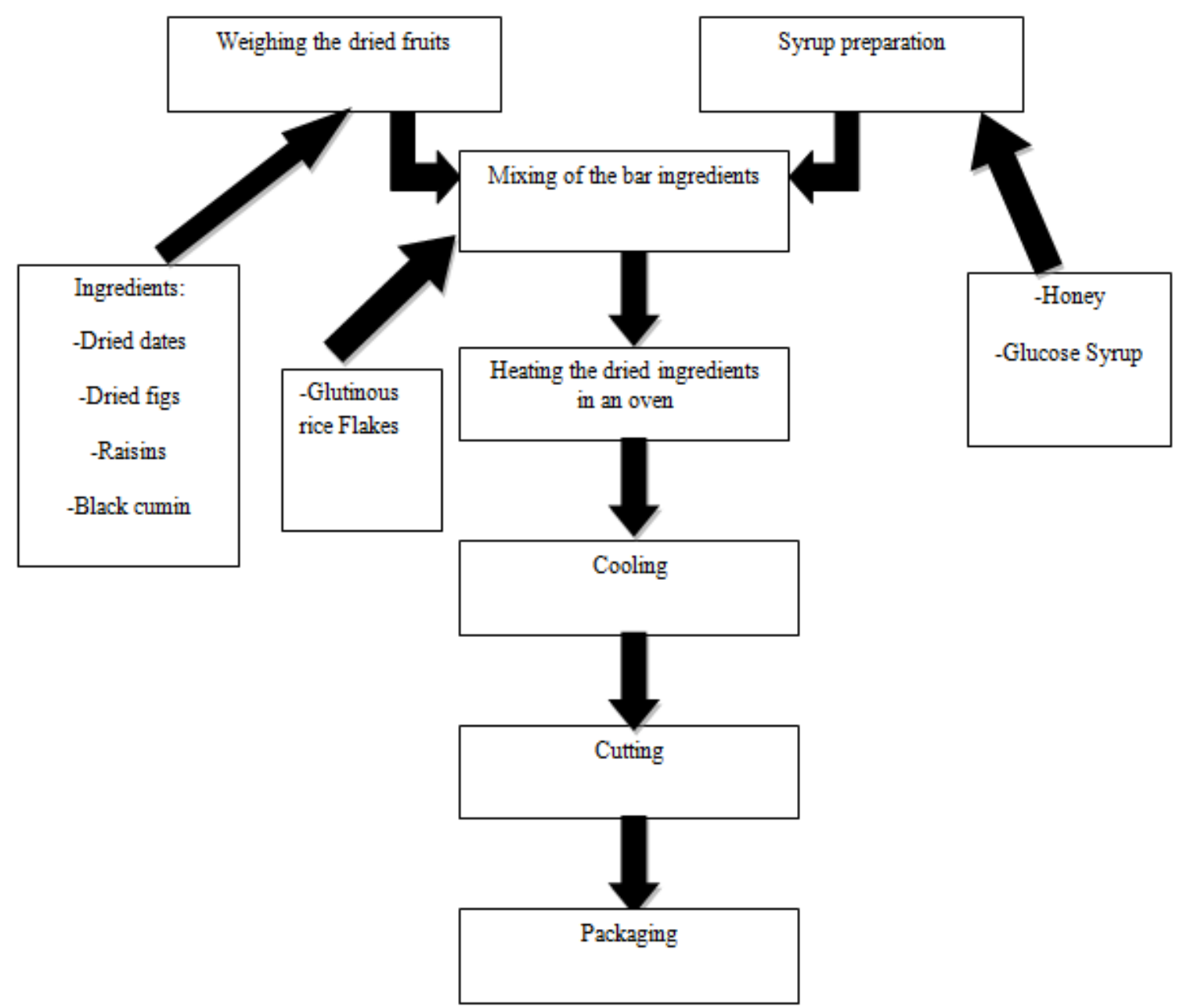

Fig. 4.1. General flow chart for the manufacture of glutinous rice flakes /Sunnah fruits bars

\section{CONCLUSION}

The use of glutinous rice that is gluten-free makes the cereal bar to cut across varied consumers. The cereal bars can be consumed by celiac disease patients because it contains no gluten. The fruits used in the development of the bar formulations may prove to be a good snack for school going children to meet their body development needs .Based on the results obtained, we could conclude that the cereal bar produced from Sunnah foods like figs, dates and raisins satisfactorily contribute to nutritional values if compared to others in the market. It was also evident from the results that a nutritious and Halal cereal bar can be produced by using glutinous rice flakes, figs, saffron, dates, raisins and binders containing glucose syrup and honey.

Conclusively, Sunnah foods like raisins, dates and figs can be used successfully to develop new formulation of cereal bars. In term of nutrition, they can be regarded as a well -balanced snacks (Ready to Eat).

\section{Acknowledgements}

The authors would like to thank the Institution: Universiti Sains Islam Malaysia for the availability of resources and technology for the development of this research and INZ PADU CORPORATION SDN BHD for the financial support for execution of this project. 


\section{REFERENCES}

[1] T.Nagai, R. Inoue, N. Kanamori, N. Suzuki and T. Nagashima, Characterization of honey from different floral sources. Its functional properties and effects of honey species on storage of meat. Food Chemistry. 9, 2006, 256-262.

[2] I .Brito, J. Campos, T. Souza, C. Wakiyama, and G. Azeredo, Preparation and evaluation of global homemade cereal bars, Bulletin of the Research Center of Food Processing, 22, 2004, 35-50.

[3] D. Sun-Waterhouse, A. Teoh, C. Massarotto, R. Wibisono, and S. Wadhwa, Comparative analysis of fruit-based functional snack bars. Food Chemistry, 119 (4), 2010 1369-1379.

[4] M. Foschia, D. Peressini, A. Sensidoni, and C. S. Brennan, The effects of dietary fibre addition on the quality of common cereal products. Journal of Cereal Science, 58, 2013, 216-227.

[5] E.C. Silva, V.S. Sobrinho, and M.P Cereda, Stability of cassava flour-based food bars. Food Science and Technology Campinas, 33, 2013, 192-198.

[6] I.S.M. Macedo, M.J. Sousa-Gallagher, J.C. Oliveira, and E.P. Byrne. Quality by design for packaging of granola breakfast product. Food Control, 29, 2013, 438-443.

[7] S.D. Dutcosky, M.V.E. Grossmann, R.S.S.F. Silva, and A.K. Welsch,. Combined sensory optimization of a prebiotic cereal product using multicomponent mixture experiments. Food Chemistry 98, 2006, 630-638.

[8] D. Ryland, M .Vaisey-Genser, S.D. Arntfield, J. Linda, L.J Malcolmson, Development of a nutritious acceptable snack bar using micronized flaked lentils. Food Resources International, 43, 2010, 642-649.

[9] A.C. Lima, Study for the aggregation of heat to cashew products: preparation of formulations of fruits and brown bars. State University of Campinas, Campinas- SP, Brazil, PhD, 2004.

[10] A. Addeen, S. Benjakul, S. Wattanachant, and S. Maqsood, Effect of Islamic slaughtering on chemical compositions and postmortem quality changes of broiler chicken meat. International Food Research Journal 21(3), 2014, 897-907.

[11] J.M. Regenstein, M.M. Chaudry, and C.E. Regenstein, The Kosher and halal food laws. Comprehensive Reviews in Food Science and Food Safety 2, 2003, 111-127.

[12] K. Bonne, and W. Verbeke, Muslim consumer trust in halal meat status and control in Belgium. Meat Science, 79, $2008,113-123$.

[13] A.R. Sam, and C.Z. Alvarado, Turkey carcass chilling and protein denaturation in the development of pale, soft and exudative meat. Poultry Science, 83, 2001, 1046-1093.

[14] A. Stone, and J. Sidel, Sensory evaluation practice (Academic Press, New York, USA, 1993).

[15] G.C. Freitas, and R.H. Moretti, Characterization and sensory evaluation of functional cereal bar high content protein and vitamin. Science and Food Technology, 26, 2006, 318-324.

[16] M. G. Carvalho, J. M.C. Costa, M. C. P. Rodrigues, P. H. M. Sousa and E. Clemente. Formulation and Sensory Acceptance of Cereal-Bars Made with Almonds of chichá, sapucaia and gurguéia Nuts. The Open Food Science Journal, 5 2011, $26-30$.

[17] C.T. Santos, R. F. Bonomo, R.C. I. Fontan, P. Bonomo, C. M. Veloso and G. C. R. Fontan. Characterization and sensorial evaluation of cereal bars with jackfruit. Acta Scientiarum. Technology Maringá, 33(1), 2011, 81-85.

[18] L. M. Pagamunici, A.H.P. Souza, A. K. Gohara, N. E. Souza, S. T. M. Gomes, and M. Matsushita. Development, Characterization and Chemometric Analysis of a gluten-free Food bar containing whole flour from a new cultivar of Amaranth. Maringa, 38(3), 2014, 270-277.

[19] H.T. Lawless, and H Heyman, Sensory evaluation of food: principles and practices, in Second edition,( Berlin: Springer- 2010) Page 586.

[20] E. R. Torres, E. S. Castro, R. F. Santana, J. C. Cardoso, C. M. F. Soaresa, and Á. S. Lima. Cereal bar Development Using Exotic Fruit, Proc. 11th ICEF Conf. on Engineering and Food, "Food Process Engineering in a Changing World", Athens, Greece, 2011.

[21] P. Ananthan, K.S. Gopal, G. Thimma, Development and Evaluation of Shelf Stability of Flaxoat Nutty Bar in Different Packaging Materials. Food and Nutrition Sciences, 4, 2013, 538-546.

[22] P. Ananthan, K.S. Gopal, A.S. Kadaba, S.B. Amarinder, Development of shelf stable protein rich composite cereal bar. Journal of Food Science and Technology, 49, 2012, 335-341.

[23] J.N. Hathcock, Vitamin and mineral safety, in Council for Responsible Nutrition, $2^{\text {nd }}($ Ed). Washington- 2004 , page 169.

[24] L.M. Pagamunici, A. H. P. Souza, A. K. Gohara, N. E. Souza, S. T. M. Gomes, M. Matsushita, Development, Characterization and Chemometric Analysis of a gluten-free Food bar containing whole flour from a new cultivar of Amaranth. Maringa, 38(3), 2014, $270-277$.

[25] S. Rehman, M.N. Nadeem and J.A. Awan, Development and physic-chemical characterization of apricot-date bars. Journal of Agricultural Research. 50, 2012. 409-421. 